\title{
Effect of Cyantraniliprole on Feeding Cessation of Q Biotype Bemisia tabaci (Gennadius) (Hemiptera: Aleyrodidae)
}

\author{
Rameshwar Singh Rattan1, Hardik Purohit'1, Chandni Patel1', Pankaj Suvagia1, \\ Vineet Singh', Hector Portillo², I. Billy Annan'2, Juan M. Alvarez ${ }^{2}$ \\ ${ }^{1}$ DuPont Crop Protection, E.I. DuPont India Pvt. Ltd., South Asia Field Experimental Station, Vadodara, India \\ ${ }^{2}$ DuPont Crop Protection, Stine-Haskell Research Center, Newark, USA \\ Email: rameshwar-singh.rattan@dupont.com
}

Received 3 March 2015; accepted 21 April 2015; published 24 April 2015

Copyright (C) 2015 by authors and Scientific Research Publishing Inc.

This work is licensed under the Creative Commons Attribution International License (CC BY). http://creativecommons.org/licenses/by/4.0/ (c) (i) Open Access

\section{Abstract}

The whitefly, Bemisia tabaci (Hemiptera: Aleyrodidae) is one of the most devastating agricultural pests in many cropping systems worldwide. Growers rely on the use of insecticides to control this pest. However, some insecticides do not reduce the feeding of $B$. tabaci fast enough to prevent the direct and indirect damage produced by this insect. The effect of a new insecticide, cyantraniliprole 100D (Cyazypyr ${ }^{\mathrm{TM}}$ ), on the feeding of $B$. tabaci adults, was studied under laboratory conditions. Cyantraniliprole 100D is an insecticide that belongs to the IRAC Group 28 with a new mode of action for sucking insects, which provides rapid feeding cessation by impairing muscle function, resulting in reduced transmission of important insect vectored crop diseases. Laboratory experiments were conducted to determine the effect of cyantraniliprole along with some other commercially available insecticides on the feeding of $B$. tabaci adults by measuring the excretion of honeydew as an indirect assessment of insect feeding. In these experiments, cyantraniliprole resulted in significantly higher reduction of honeydew excretion (64.0\%) by $Q$ biotype $B$. tabaci adults during the first 30 minutes of exposure than diafenthiuron, triazophos, acetamiprid and spiromesifen, with all treatments having no adult mortality. Observations between 1 and 48 hours after exposure indicated that cyantraniliprole had numerically higher or similar reduction in honeydew production as the other insecticides, but by 48 hours (mid and high rate) and 96 hours (high rate) of exposure, cyantraniliprole had significantly higher reduction of honeydew excretion than all other insecticides tested. Low adult mortality was observed during first 24 hours of exposure in all treatments. Cyantraniliprole resulted in numerical or significantly higher adult mortality than all other treatments at the later observation intervals (72 - 96 hours). The higher reduction in honeydew excretion by cyantraniliprole appeared to be related to faster feeding cessation during the initial hours of exposure by a combination of feeding cessation and direct mortality as the exposure time 
increased. These findings document significant effects of cyantraniliprole on feeding cessation in Bemisia tabaci.

\title{
Keywords
}

\author{
Bemisia tabaci, Cyazypyr ${ }^{\mathrm{TM}}$, Cyantraniliprole, Benevia ${ }^{\mathrm{TM}}$, Feeding Cessation
}

\section{Introduction}

The cotton or sweet potato whitefly, B. tabaci (Gennadius), is an important hemipteran pest of a vast range of field and greenhouse crops [1]. Agricultural losses of millions of dollars have been attributed to B. tabaci [2]-[7]. The pest causes losses of yield and quality directly through feeding damage and indirectly by vectoring plant viral diseases [8]. Extraction of large quantities of phloem sap can eventually lead to plant death under high whitefly densities. B. tabaci adults and immature stages excrete honeydew during feeding, which provides a source of carbon and nitrogen for the growth of sooty mold fungi that causes great damage to host plants by blocking photosynthesis and propagating other species of fungi [9]. The honeydew stains also reduce the quality and consequently the economic value of produce. For example, honeydew deposits on cotton lint and adheres to the working surfaces of cotton processing equipment, resulting in reduced ginning rates and damage to lint processing machinery at the textile mill [10]. B. tabaci has been reported to transmit more than 110 plant pathogenic viruses [8]. Early infection of these $B$. tabaci transmitted viruses often results in total crop loss [11]. Insecticides are used intensively around the world for the management of $B$. tabaci and to minimize viral spread. However, few insecticides provide control of the insects and reduce disease transmission to satisfactory economic levels. Failures to control B. tabaci have been reported with the development of insecticide resistance to active ingredients from different chemical classes [12]-[19]. Cyantraniliprole is the second active ingredient in the anthranilic diamide class discovered by the DuPont Company, and the first in this class to provide cross-spectrum control of chewing and sucking pests. Cyantraniliprole is classified by the Insect Resistance Action Committee (IRAC) as a ryanodine receptor modulator, in Group 28, and shares this mode of action with two other commercial diamides: chlorantraniliprole and flubendiamide [20].

Cyantraniliprole selectively activates the ryanodine receptors in insect muscles, resulting in rapid feeding cessation. This rapid feeding cessation has been correlated with reduction of some insect-vectored plant diseases in the field [21]-[26]. The excretion of honeydew by B. tabaci adults has previously been used as an indirect assessment of insect feeding [27] [28]. Laboratory experiments were conducted to evaluate the impact of cyantraniliprole $10 \mathrm{OD}$ and some other commercially available insecticides on honeydew excretion by $B$. tabaci $\mathrm{Q}$ biotype adults following foliar application.

\section{Materials and Methods}

\subsection{Whitefly Rearing}

A field population of B. tabaci Q biotype (PCR studies conducted at Insect Molecular Biology Laboratory, Department of Entomology, Punjab Agricultural University, Ludhiana, India) was collected from a local farm at Vadodara, India in April 2011 and maintained in the greenhouse on eggplant, Solanum melongena L. (Solanales: Solanaceae). A sub colony was maintained in the laboratory for two generations on individually caged eggplants at $27^{\circ} \mathrm{C} \pm 2^{\circ} \mathrm{C}$ and relative humidity of $65 \% \pm 5 \%$ with a photoperiod of $14: 10$ hours (L:D) in rearing cages (60 $\times 60 \times 60 \mathrm{~cm}$ ) before being used in the experiments.

\subsection{Plants}

Cotton plants (var. MRC-non $B t$, Mahyco India) used in the experiments were grown in a greenhouse in pots (12 $\mathrm{cm}$ dia) containing a mixture comprising equal units of soil, sand and vermicompost and maintained at $30^{\circ} \mathrm{C}$.

\subsection{Insect Test Unit}

Cotton plants with three fully expanded leaves (about 20 days old) were used for the experiment. A mylar disk 
$\left(19 \mathrm{~cm} \mathrm{dia}\right.$, Lexan $^{\mathrm{TM}}$, Star Plast, India) with a cut from the edge to the center was fitted around the stem of each plant and placed directly on top of the pot (Figure 1). A filter paper $\left(185 \mathrm{~mm}\right.$ dia, Whatman ${ }^{\mathrm{TM}}$ No. 1; GE Healthcare UK Limited, UK) was placed on top of the mylar disk to protect the filter paper from contact with water, soil or any other contaminant from the pot. The weight of the filter paper was recorded before placing it on top of the mylar disk. Test units were isolated from each other using mylar cylinder cages $(17 \mathrm{~cm} \mathrm{dia} \times 20 \mathrm{~cm}$ height).

\subsection{Insecticide Treatments}

Cyantraniliprole 10OD at three rates: $60,90,120 \mathrm{~g}$ of active ingredient per ha (g a.i./ha) (Benevia ${ }^{\mathrm{TM}}$ 10OD: E.I. DuPont India Pvt. Ltd, India) was compared to four commercial insecticides, commonly used for whitefly control, at their equivalent use field rates labeled in India: acetamiprid 20SP (IRAC group: 4A-Nicotinic acetylcholine receptor (nAChR agonists) [20] at $40 \mathrm{~g}$ a.i./ha (RekordTM: E.I. DuPont India Pvt. Ltd, India), triazophos 40 EC (IRAC group: 1B- Acetylcholinesterase (AChE inhibitors) [20] at $500 \mathrm{~g}$ a.i./ha (Trex: New Chemi Industries Ltd., India), diafenthiuron 50WP (IRAC group: 12A- Inhibitors of mitochondrial ATP synthase) [20] at $300 \mathrm{~g}$ a.i./ha (Polo ${ }^{\circledR}$ : Syngenta India Ltd, India) and spiromesifen 22.9SC (IRAC group: 23- Inhibitors of lipid synthesis) [20] at $240 \mathrm{~g}$ a.i./ha (Oberon ${ }^{\circledR}$ : Bayer CropScience, India). A set of plants sprayed with water were used as untreated control.

\subsection{Spray Application}

All insecticide solutions were sprayed using a microsprayer: W3019530 (DuPont Crop Protection, Stine Haskell, Newark, DE USA) at 18 psi (nozzle-LEGRIS1/8) and air dried for one hour in a ventilated enclosure at room temperature before plants were infested with B. tabaci Q biotype adults. All solutions were prepared the day of the experiment in distilled water. The experiment was repeated two times with three replications in each test.

\subsection{B. tabaci Infestation and Estimation of Feeding Cessation}

Newly emerged B. tabaci Q biotype adults ( $c a .12$ hours old) were collected from the laboratory sub colony and starved for one hour. Fifty starved whitefly adults were anesthetized with $\mathrm{CO}_{2}$ at 5 psi for one minute and released in the insect test units. The mylar cylinder cage was covered with muslin cloth at the top to avoid escape of whitefly adults (Figure 1).

Estimation of feeding activity was indirectly assessed by measuring honeydew excretion by $B$. tabaci adults in treated and untreated plants. Honeydew droplets excreted by whitefly adults were deposited on the filter paper. Honeydew excretion by $B$. tabaci adults was calculated by recording the difference between filter paper weights before placement and after they were removed from the insect test units at 0.5, 1, 2, 4, 6, 12, 24, 48, 72 and 96 hours of exposure.
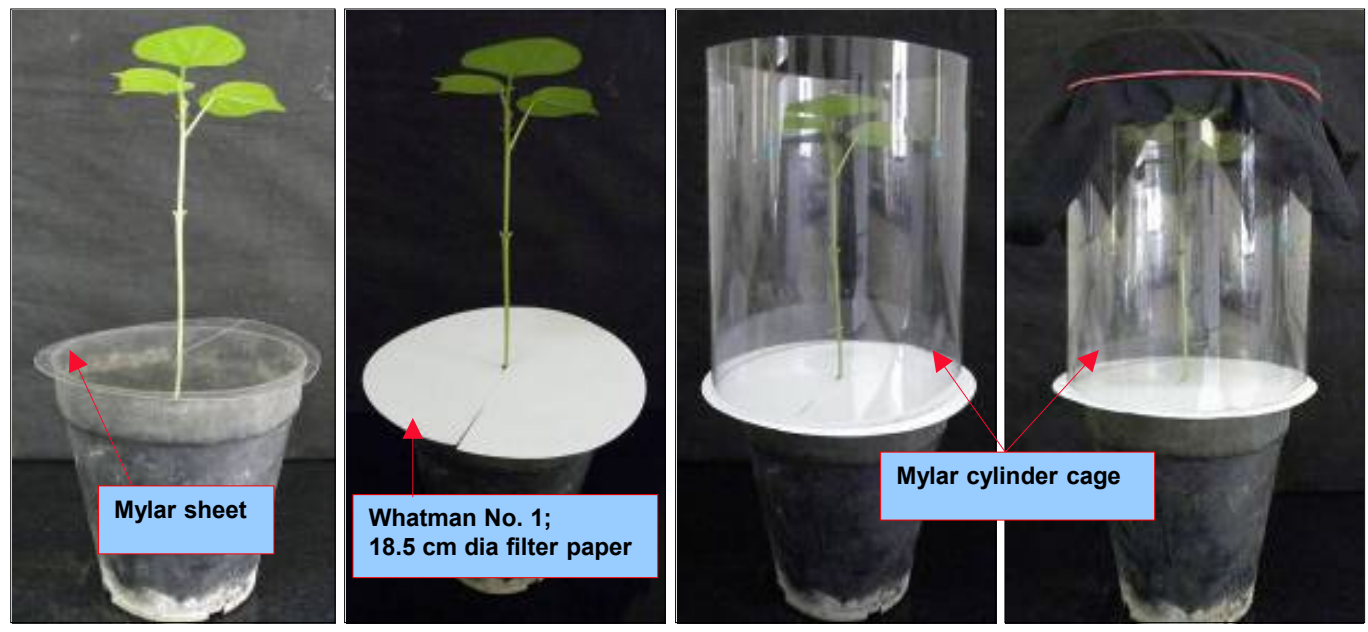

Figure 1. Insect test unit for Bemisia tabaci feeding cessation studies. 
Mortality of whitefly adults was also assessed at the same time intervals. Separate insect test units with untreated plants were kept for each time interval to ensure no impact on feeding due to handling during the experimental period. The insect test units were maintained in the laboratory at $27^{\circ} \mathrm{C} \pm 2^{\circ} \mathrm{C}, \mathrm{RH}: 65 \% \pm 5 \%$ and $14: 10$ (L: D) hour photoperiod. Filter papers were weighed and the droplets of honeydew deposited on them were visualized by spraying 1.0\% ninhydrin (Merck Specialties Pvt. Ltd., India) solution in acetone and drying the paper for 5 minutes at $100^{\circ} \mathrm{C}$. The honeydew droppings appeared violet or purple in color due to presence of amino acid contents and were visible to the naked eye, which ascertained the presence of honeydew droppings on the filter paper. Data obtained from weighing filter papers (weight difference before and after whitefly infestation) and mortality was subjected to analysis of variance (ANOVA) and treatment means were compared using Duncan's Multiple Range Test (DMRT) at 5\% level of significance.

\section{Results}

\subsection{Estimation of Feeding Cessation}

Honeydew deposition increased through all time intervals in the untreated control and was significantly higher than honeydew deposition in all insecticide treatments (Table 1). A numerical dose response was observed within all cyantraniliprole treatments (Table 1). At 48 hours, a significantly lower deposition of honeydew was observed in the mid and high rates of cyantraniliprole when compared to all other treatments. After 72 hours, a significantly lower amount of honeydew deposition was observed in all cyantraniliprole treatments as compared to rest of the insecticides tested. Honeydew deposition with all cyantraniliprole treatments remained statistically lower than all other insecticides at 96 hours.

Data on percent decrease in honeydew excretion with respect to the untreated control is presented in Table 2. The data shows that the highest rate of cyantraniliprole resulted in the highest significant reduction of honeydew

Table 1. Effect of several insecticides on honeydew excretion in Bemisia tabaci adults recorded at different time intervals using the weight difference.

\begin{tabular}{|c|c|c|c|c|c|c|c|c|c|c|c|}
\hline \multirow{2}{*}{ Treatments } & \multicolumn{11}{|c|}{ Honeydew deposition based on weight difference (mg) at different time intervals (hours) } \\
\hline & 0.5 & 1 & 2 & 3 & 4 & 6 & 12 & 24 & 48 & 72 & 96 \\
\hline Cyantraniliprole $10 \mathrm{OD}$ at $60 \mathrm{~g}$ a.i./ha & $8.3 \mathrm{~b}$ & $14.3 \mathrm{bc}$ & $16.6 \mathrm{bc}$ & $18.6 \mathrm{~b}$ & $19.0 \mathrm{~b}$ & $20.2 \mathrm{~b}$ & $22.2 \mathrm{~b}$ & $22.1 \mathrm{~b}$ & $20.2 \mathrm{de}$ & $17.6 \mathrm{~d}$ & $16.8 \mathrm{ef}$ \\
\hline Cyantraniliprole $10 \mathrm{OD}$ at $90 \mathrm{~g}$ a.i./ha & $5.6 \mathrm{~cd}$ & $14.5 \mathrm{bc}$ & $15.2 \mathrm{c}$ & $16.2 \mathrm{de}$ & $17.3 \mathrm{bc}$ & $18.8 \mathrm{bc}$ & $20.8 \mathrm{bc}$ & $21.0 \mathrm{bc}$ & 18.8 ef & $17.1 \mathrm{~d}$ & $15.6 \mathrm{f}$ \\
\hline Cyantraniliprole $10 \mathrm{OD}$ at $120 \mathrm{~g}$ a.i./ha & $4.5 \mathrm{~d}$ & $11.6 \mathrm{c}$ & $14.0 \mathrm{c}$ & $14.8 \mathrm{e}$ & $16.6 \mathrm{c}$ & $17.5 \mathrm{~d}$ & $18.5 \mathrm{~d}$ & $19.1 \mathrm{~d}$ & $16.8 \mathrm{f}$ & $15.6 \mathrm{~d}$ & $14.5 \mathrm{f}$ \\
\hline Acetamiprid $20 \mathrm{SP}$ at $40 \mathrm{~g}$ a.i. $/ \mathrm{ha}$ & $9.3 \mathrm{~b}$ & $16.0 \mathrm{ab}$ & $15.5 \mathrm{bc}$ & $16.5 \mathrm{cde}$ & $16.8 \mathrm{c}$ & $17.8 \mathrm{~cd}$ & $18.0 \mathrm{~d}$ & $20.8 \mathrm{bc}$ & $24.6 \mathrm{bc}$ & $23.6 \mathrm{c}$ & $22.2 \mathrm{c}$ \\
\hline Triazophos $40 \mathrm{EC}$ at $500 \mathrm{~g}$ a.i. $/ \mathrm{ha}$ & $8.6 \mathrm{~b}$ & $16.5 \mathrm{ab}$ & $16.5 \mathrm{bc}$ & $17.8 \mathrm{bcd}$ & $17.8 \mathrm{bc}$ & $19.0 \mathrm{bc}$ & $18.3 \mathrm{~d}$ & $21.8 \mathrm{bc}$ & $22.0 \mathrm{~cd}$ & $23.5 \mathrm{c}$ & $19.0 \mathrm{de}$ \\
\hline Diafenthiuron 50WP at $300 \mathrm{~g}$ a.i./ha & $8.5 \mathrm{~b}$ & $17.0 \mathrm{ab}$ & $15.3 \mathrm{bc}$ & $17.5 \mathrm{bcd}$ & $17.8 \mathrm{bc}$ & $19.2 \mathrm{bc}$ & $18.0 \mathrm{~d}$ & $20.3 \mathrm{~cd}$ & $23.8 \mathrm{c}$ & $23.6 \mathrm{c}$ & $20.5 \mathrm{~cd}$ \\
\hline Spiromesifen $22.9 \mathrm{SC}$ at $240 \mathrm{~g}$ a.i./ha & $8.0 \mathrm{bc}$ & $14.6 \mathrm{bc}$ & $19.8 \mathrm{ab}$ & $18.3 \mathrm{bc}$ & $18.8 \mathrm{~b}$ & $20.0 \mathrm{~b}$ & $19.5 \mathrm{~cd}$ & $22.5 \mathrm{~b}$ & $27.0 \mathrm{~b}$ & $29.0 \mathrm{~b}$ & $27.6 \mathrm{~b}$ \\
\hline Untreated & $12.6 \mathrm{a}$ & $19.2 \mathrm{a}$ & $23.3 \mathrm{a}$ & $26.5 \mathrm{a}$ & $27.3 \mathrm{a}$ & $28.2 \mathrm{a}$ & $29.8 \mathrm{a}$ & $31.3 \mathrm{a}$ & $32.6 \mathrm{a}$ & $33.8 \mathrm{a}$ & $35.2 \mathrm{a}$ \\
\hline
\end{tabular}

The treatment means are separated using Duncan's MRT. Treatment means sharing the same letters are not significantly different from each other $(\alpha$ $=0.05)$.

Table 2. Effect on honeydew deposition in Bemisia tabaci adults after the treatment with several insecticides.

\begin{tabular}{cccccccccccc}
\hline & \multicolumn{6}{c}{ Percent decrease in honey dew deposition/excretion with respect to untreated control (mg) } \\
\cline { 2 - 9 } Treatments & 0.5 & 1 & 2 & 3 & 4 & 6 & 12 & 24 & 48 & 72 & 96 \\
\hline Cyantraniliprole 10OD at $60 \mathrm{~g}$ a.i./ha & $32.5 \mathrm{bc}$ & $24.1 \mathrm{a}$ & $28.4 \mathrm{ab}$ & $29.5 \mathrm{c}$ & $29.8 \mathrm{a}$ & $28.3 \mathrm{~b}$ & $25.2 \mathrm{c}$ & $29.3 \mathrm{~cd}$ & $39.2 \mathrm{ab}$ & $51.1 \mathrm{a}$ & $52.1 \mathrm{ab}$ \\
Cyantraniliprole 10OD at 90 g a.i./ha & $54.5 \mathrm{ab}$ & $22.9 \mathrm{a}$ & $34.8 \mathrm{a}$ & $38.9 \mathrm{ab}$ & $36.2 \mathrm{a}$ & $32.9 \mathrm{ab}$ & $29.8 \mathrm{bc}$ & $32.9 \mathrm{bcd}$ & $42.3 \mathrm{ab}$ & $49.2 \mathrm{a}$ & $55.4 \mathrm{ab}$ \\
Cyantraniliprole 10OD at $120 \mathrm{~g}$ a.i./ha & $64.0 \mathrm{a}$ & $37.6 \mathrm{a}$ & $39.9 \mathrm{a}$ & $43.9 \mathrm{a}$ & $38.3 \mathrm{a}$ & $37.8 \mathrm{a}$ & $37.7 \mathrm{ab}$ & $38.7 \mathrm{a}$ & $48.4 \mathrm{a}$ & $53.6 \mathrm{a}$ & $58.6 \mathrm{a}$ \\
Acetamiprid 20SP at 40 g a.i./ha & $26.0 \mathrm{c}$ & $15.2 \mathrm{a}$ & $33.7 \mathrm{ab}$ & $37.5 \mathrm{abc}$ & $37.9 \mathrm{a}$ & $36.5 \mathrm{a}$ & $39.5 \mathrm{a}$ & $33.4 \mathrm{abc}$ & $24.4 \mathrm{~cd}$ & $29.8 \mathrm{~b}$ & $36.8 \mathrm{~cd}$ \\
Triazophos 40EC at 500 g a.i./ha & $31.8 \mathrm{bc}$ & $12.1 \mathrm{a}$ & $29.0 \mathrm{ab}$ & $32.7 \mathrm{bc}$ & $34.3 \mathrm{a}$ & $32.4 \mathrm{ab}$ & $38.4 \mathrm{ab}$ & $30.2 \mathrm{bcd}$ & $32.5 \mathrm{bc}$ & $30.4 \mathrm{~b}$ & $45.8 \mathrm{bc}$ \\
Diafenthiuron 50WP at 300 g a.i./ha & $32.2 \mathrm{bc}$ & $9.6 \mathrm{a}$ & $33.7 \mathrm{ab}$ & $34.0 \mathrm{bc}$ & $34.2 \mathrm{a}$ & $31.7 \mathrm{ab}$ & $39.6 \mathrm{a}$ & $35.1 \mathrm{ab}$ & $26.7 \mathrm{~cd}$ & $30.0 \mathrm{~b}$ & $34.9 \mathrm{~d}$ \\
Spiromesifen 22.9SC at 240 g a.i./ha & $35.6 \mathrm{bc}$ & $22.0 \mathrm{a}$ & $15.0 \mathrm{~b}$ & $30.7 \mathrm{c}$ & $30.6 \mathrm{a}$ & $28.9 \mathrm{~b}$ & $34.4 \mathrm{ab}$ & $28.1 \mathrm{~d}$ & $17.2 \mathrm{~d}$ & $14.2 \mathrm{c}$ & $21.2 \mathrm{e}$ \\
\hline
\end{tabular}

The treatment means are separated using Duncan's MRT. Treatment means sharing the same letters are not significantly different from each other $(\alpha$ $=0.05)$. 
excretion $(64.0 \%) 30$ minutes after the initiation of the experiment as compared to all other insecticidal treatments which was directly proportional to dose increase of the insecticide. Among the standard insecticides, spiromesifen showed highest reduction in honeydew deposition at this evaluation time (35.6\%) (Figure 2).

Although not significantly different, the percent reduction in honeydew production was higher for the high rate of cyantraniliprole treatment during all the sampling periods up to 6 hours after infestation as compared to all other treatments. Minor statistical differences were observed between treatments until 48 hours after the initiation of the experiment, when all the cyantraniliprole treatments significantly reduced the honeydew excretion compared to standard checks. Significant reductions were observed in cyantraniliprole treatments when compared to all standard insecticides at 72 and 96 hours after the initiation of the experiment.

\subsection{B. tabaci Mortality}

It was observed that B. tabaci settled on the treated plants within $15-20$ minutes of release and no mortality was observed in any of the treatments up to 30 minutes after inoculation. No mortality was observed in the untreated checks during the course of the experiment. Percent mortality ranged from 1.6 to 4.0 in all treatments within one hour after infestation. The mortality in the cyantraniliprole treatment at $120 \mathrm{~g}$ a.i./ha was significantly higher than the one in the acetamiprid, triazophos, diafenthiuron and spiromesifen treatments at all the observation intervals (Table 3). Mortality increased with time in all concentrations of cyantraniliprole and a dose response was observed. After 96 hours of insecticide treatment, a significant higher mortality (74.6\%) was observed with cyantraniliprole at $120 \mathrm{~g}$ a.i./ha, as compared to cyantraniliprole at 60 and $90 \mathrm{~g}$ a.i./ha and all other commercial insecticides

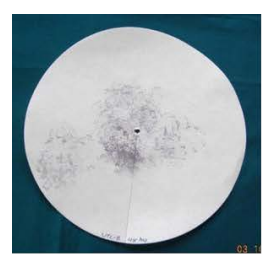

Untreated

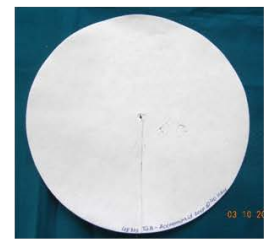

Acetamiprid 20SP at $40 \mathrm{~g}$ ai/ha

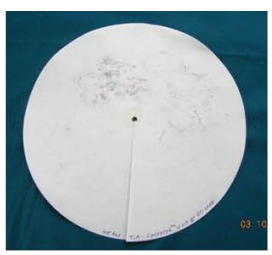

Cyantraniliprole $100 \mathrm{D}$ at $60 \mathrm{~g}$ ai/ha

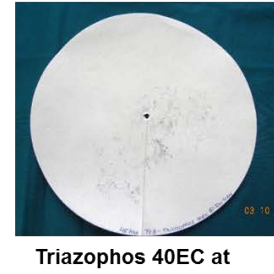

$500 \mathrm{~g} \mathrm{ai} / \mathrm{ha}$

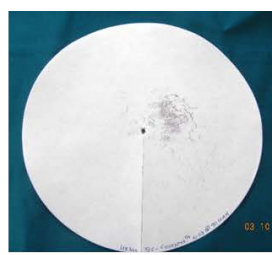

Cyantraniliprole $100 \mathrm{D}$ at $90 \mathrm{~g} \mathrm{ai} / \mathrm{ha}$

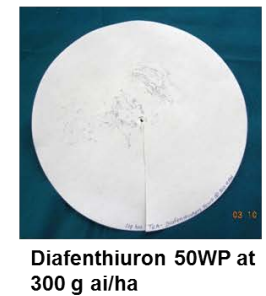

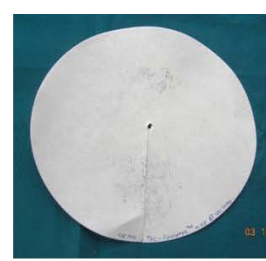

Cyantraniliprole $100 \mathrm{D}$ at $120 \mathrm{~g}$ ai/ha

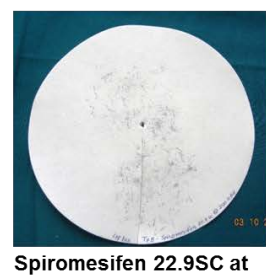

$240 \mathrm{~g}$ ai/ha

Figure 2. Spots of honeydew excretion/deposition after 48 hours of insecticide application.

Table 3. Percent mortality of Bemisia tabaci adults on insecticide treated plants.

\begin{tabular}{ccccccccccccc}
\hline \multirow{2}{*}{ Treatments } & \multicolumn{8}{c}{ Percent mortality in B. tabaci adults at different intervals (hours) } \\
\cline { 2 - 11 } & 0.5 & 1 & 2 & 3 & 4 & 6 & 12 & 24 & 48 & 72 & 96 \\
\hline Cyantraniliprole 10OD at $60 \mathrm{~g}$ a.i./ha & 0.0 & $1.6 \mathrm{~cd}$ & $3.0 \mathrm{~b}$ & $5.6 \mathrm{c}$ & $6.3 \mathrm{c}$ & $8.6 \mathrm{~d}$ & $15.3 \mathrm{c}$ & $20.3 \mathrm{~d}$ & $23.3 \mathrm{c}$ & $27.3 \mathrm{c}$ & $60.3 \mathrm{bc}$ \\
Cyantraniliprole 10OD at $90 \mathrm{~g}$ a.i./ha & 0.0 & $2.3 \mathrm{abc}$ & $4.6 \mathrm{ab}$ & $8.6 \mathrm{ab}$ & $9.6 \mathrm{~b}$ & $12.0 \mathrm{~b}$ & $19.3 \mathrm{~b}$ & $24.3 \mathrm{c}$ & $35.0 \mathrm{~b}$ & $40.6 \mathrm{~b}$ & $62.3 \mathrm{~b}$ \\
Cyantraniliprole 10OD at $120 \mathrm{~g}$ a.i./ha & 0.0 & $3.6 \mathrm{ab}$ & $6.0 \mathrm{a}$ & $10.0 \mathrm{a}$ & $12.6 \mathrm{a}$ & $14.0 \mathrm{a}$ & $23.0 \mathrm{a}$ & $32.6 \mathrm{a}$ & $45.6 \mathrm{a}$ & $53.6 \mathrm{a}$ & $74.6 \mathrm{a}$ \\
Acetamiprid 20SP at $40 \mathrm{~g}$ a.i./ha & 0.0 & $1.6 \mathrm{~cd}$ & $4.0 \mathrm{~b}$ & $6.0 \mathrm{c}$ & $7.6 \mathrm{bc}$ & $10.0 \mathrm{~cd}$ & $15.3 \mathrm{c}$ & $27.0 \mathrm{bc}$ & $38.0 \mathrm{~b}$ & $40.6 \mathrm{~b}$ & $49.3 \mathrm{~d}$ \\
Triazophos 40EC at 500 g a.i./ha & 0.0 & $4.0 \mathrm{a}$ & $6.0 \mathrm{a}$ & $7.3 \mathrm{bc}$ & $9.6 \mathrm{~b}$ & $12.3 \mathrm{ab}$ & $18.6 \mathrm{~b}$ & $29.6 \mathrm{ab}$ & $35.3 \mathrm{~b}$ & $39.3 \mathrm{~b}$ & $56.0 \mathrm{c}$ \\
Diafenthiuron 50WP at 300 g a.i./ha & 0.0 & $1.6 \mathrm{~cd}$ & $4.0 \mathrm{~b}$ & $5.6 \mathrm{c}$ & $8.0 \mathrm{bc}$ & $11.0 \mathrm{bc}$ & $15.6 \mathrm{c}$ & $27.0 \mathrm{bc}$ & $36.6 \mathrm{~b}$ & $40.6 \mathrm{~b}$ & $60.3 \mathrm{bc}$ \\
Spiromesifen 22.9SC at 240 g a.i./ha & 0.0 & $2.0 \mathrm{bc}$ & $4.0 \mathrm{~b}$ & $6.6 \mathrm{bc}$ & $7.6 \mathrm{bc}$ & $10.6 \mathrm{bc}$ & $12.0 \mathrm{~d}$ & $11.6 \mathrm{e}$ & $14.3 \mathrm{~d}$ & $21.6 \mathrm{~d}$ & $28.3 \mathrm{e}$ \\
Untreated & 0.0 & $0.0 \mathrm{~d}$ & $0.0 \mathrm{c}$ & $0.0 \mathrm{~d}$ & $0.0 \mathrm{~d}$ & $0.0 \mathrm{e}$ & $0.0 \mathrm{e}$ & $0.0 \mathrm{f}$ & $0.0 \mathrm{e}$ & $0.0 \mathrm{e}$ & $0.0 \mathrm{f}$ \\
\hline
\end{tabular}

The treatment means are separated using Duncan's MRT. Treatment means sharing the same letters are not significantly different from each other $(\alpha$ $=0.05)$. 
tested. At this evaluation time, significantly lower mortality was observed in acetamiprid and spiromesifen when compared to all three doses of cyantraniliprole. Diafenthiuron and triazophos were next to cyantraniliprole in respect of whitefly mortality ( $60.3 \%$ and $56 \%$ mortality, respectively), 96 hours after treatment.

\section{Discussion}

B. tabaci nymphs and adults feed in the phloem and obtain sap containing various sugars [29]. Only $10 \%$ of ingestion is utilized in aphids' growth, oviposition and respiration; the rest is excreted. While what percentage of ingestion is represented by the amount of honeydew excreted by whiteflies is not known, it is still considered as a good estimate of ingestion [30]. In the absence of significant adult mortality, a reduction in the amount of honeydew produced by a sucking insect when exposed to an insecticide is likely related to its impact on the ability of the insect to feed. It was previously observed by other researchers that imidacloprid reduces the amount of honeydew production by $B$. tabaci adults [31] [32]. Similar observations were made when honeydew secretion by adults of Bemisia argentifolii was studied after treatment with imidacloprid and avermectins [33].

In the present study, percent decrease of honeydew in the cyantraniliprole $10 \mathrm{OD}$ treatment at $120 \mathrm{~g}$ a.i./ha was significantly higher (64.0\%) after 30 minutes of exposure when compared with all other treatments, indicating a rapid reduction in feeding of $B$. tabaci adults on plants treated with this insecticide. In a recent study, where fluorescence was used to determine the feeding cessation of B biotype B. tabaci nymphs, plants treated with cyantraniliprole also caused a significant reduction of feeding when compared with nymphs feeding on plants treated with imidacloprid or spirotetramat [34]. Another study showed a reduction in the amount of honeydew produced by B biotype $B$. tabaci adults in cyantraniliprole treatments equivalent to imidacloprid. The study was conducted using water sensitive paper to determine the whitefly adult feeding, when insects were exposed to insecticide-treated and untreated plants [35]. Other studies have also shown that cyantraniliprole reduces feeding of thrips [24] and aphids [25].

Commercial insecticides used in this study are well known for their efficacy against whiteflies [36]-[38], however, results from these studies show that they vary in speed of action and effect on feeding cessation. Cyantraniliprole $10 \mathrm{OD}$ at $120 \mathrm{~g}$ a.i./ha was the fastest acting insecticide (based on mortality and reduction in honeydew excretion) for $B$. tabaci adults.

Whiteflies carrying viruses in most of the cases are able to infect the plants within 4 hours of feeding [39]; insecticides that produce a rapid feeding cessation combined with a quick killing effect on adults are needed to reduce the transmission of whitefly vectored viral diseases. The present experiment shows that the reduction in honeydew excretion after treatment with cyantraniliprole 10OD is an indirect evaluation of feeding cessation which reduces feeding within 30 minutes. The presented data further showed that honeydew deposition by $B$. tabaci in cyantraniliprole 10OD treated plants decreased with time. The early reduction in feeding produced by cyantraniliprole could potentially decrease the risk of virus transmission in the early stages of plant growth. A recent study with the use of the electrical penetration graph (EPG) demonstrated that B. tabaci biotype Q adults feeding on plants treated with cyantraniliprole (foliar application) were not able to reach the phloem and consequently did not perform phloem salivation (during which inoculation of geminiviruses occurred) and phloem sap ingestion (during which geminiviruses were acquired by the whiteflies) [40]. The authors concluded that the complete failure of $B$. tabaci adults to feed from the phloem of tomato plants treated with cyantraniliprole could be due to the rapid feeding cessation produced by the mode of action of this insecticide. Therefore, the reduction in feeding could potentially have implications in the capacity of whiteflies to vector viruses and consequently in the reduction of infections caused by these viruses as well as in the decrease in sooty mold. Cantaloupe plants sprayed with cyantraniliprole 10SE (120 g a.i./ha) had fewer leaves showing Cucurbit Yellow Stunting Disorder Virus (CYSDV) symptoms and fewer adult whiteflies when compared with commercial compounds tested and the untreated control [21]. In a different system, soil applications of a 20SC formulation of cyantraniliprole applied to Capsicum annuum significantly reduced the transmission of Tomato Spotted Wilt Virus (TSWV) by Frankliniella fusca (Hinds) when compared with the water-treated control [23]. The authors correctly pointed out that "it is likely that antifeedant effects of cyantraniliprole are responsible for the decreased transmission of TSWV by $F$. fusca observed in this study". Similarly, DuPont's in-house data also showed that cyantraniliprole was highly active against both adult and nymphs of Q biotype $B$. tabaci whitefly (data not presented). This also reduces the capability of the affected pest insects to vector crop diseases [41] [42]. The unique property of rapid feeding cessation in insect pests makes cyantraniliprole a valuable addition to IPM and IRM programs in agri- 
cultural and horticultural production systems.

\section{Acknowledgements}

The authors thank DuPont Crop Protection for financial support and anonymous reviewers for their helpful comments on drafts of this manuscript.

\section{References}

[1] Servin-Villegas, R., Troyo-Dieguez, E. and Martinez-Carrillo, J.L. (2001) Wild Hosts of Bemisia argentifolii (Homoptera: Aleyrodidae) in Semiarid Northwest Mexico, Southwest. Entomology, 26, 239-244.

[2] Perring, T.M., Cooper, A.D., Rodriguez, R.J., Farrar, C.A. and Bellows Jr., T.S. (1993) Identification of a Whitefly Species by Genomic and Behavioural Studies. Science, 259, 74-77. http://dx.doi.org/10.1126/science.8418497

[3] Ellsworth, P.C. (1999) Whitefly Management in Arizona Cotton Status and Needs. In: Dugger, P. and Richter, D., Eds., Proceedings Beltwide Cotton Conferences, National Cotton Council, Memphis, 41-44.

[4] Ellsworth, P.C., Tronstad, R., Leser, J., Goodell, P.B., Godfrey, L.D., Henneberry, T.J., Hendrix, D., Brushwood, D. and Naranjo, S.E. (1999) In: Castle, S. and Nichols, R.L., Eds., Sticky Cotton Sources and Solutions, Univ. Arizona, Coop. Ext. Publ. No. AZ1156, IPM Series 13, 4 p.

[5] Oliveira, M.R.V., Henneberry, T.J. and Anderson, P. (2001) History, Current Status, and Collaborative Research Projects for Bemisia tabaci. Crop Protection, 20, 709-723. http://dx.doi.org/10.1016/S0261-2194(01)00108-9

[6] Dalton, R. (2006) Whitefly infestations: The Christmas Invasion. Nature, 443, 898-900. http://dx.doi.org/10.1038/443898a

[7] McKee, G.J., Goodhue, R.E., Zalom, F.G., Carter, C.A. and Chalfant, J.A. (2009) Population Dynamics and the Economics of Invasive Species Management: The Greenhouse Whitefly in California-Grown Strawberries. Journal of Environmental Management, 90, 561-570. http://dx.doi.org/10.1016/j.jenvman.2007.12.011

[8] Jones, D.R. (2003) Plant Viruses Transmitted by Whiteflies. European Journal of Plant Pathology, 109, $195-219$. http://dx.doi.org/10.1023/A:1022846630513

[9] Naranjo, S.E., Ellsworth, P.C., Chu, C.C., Henneberry, T.J., Riley, D.G., Watson, T.F. and Nichols, R.L. (1998) Action Thresholds for the Management of Bemisia tabaci (Homoptera: Aleyrodidae) in Cotton. Journal of Economic Entomology, 91, 1415-1426. http://dx.doi.org/10.1093/jee/91.6.1415

[10] Hector, D.J. and Hodkinson, I.D. (1989) Stickiness in Cotton. CAB International, Oxon, 43.

[11] Anderson, P.K., Hamon, A.B., Hernández, M.P. and Martin, J. (2005) Whiteflies as Vectors of Viruses in Legume and Vegetable Mixed Cropping Systems in the Tropical Lowlands of Central America, Mexico and the Caribbean. Reproductive Crop Hosts of Bemisia tabaci (Gennadius) in Latin America and the Caribbean. In: Anderson, P.K. and Morales, F.J., Eds., Whitefly and Whitefly-Borne Viruses in the Tropics: Building a Knowledge Base for Global Action, Centro Internacional de Agricultura Tropical (CIAT), Cali, 243-250.

[12] Elbert, A. and Nauen, R. (2000) Resistance of Bemisia tabaci (Homoptera: Aleyrodidae) to Insecticides in Southern Spain with Special Reference to Neonicotinoids. Pest Management Science, 56, 60-64. http://dx.doi.org/10.1002/(SICI)1526-4998(200001)56:1<60::AID-PS88>3.0.CO;2-K

[13] Ahmad, M., Arif, M.I., Ahmad, Z. and Denholm, I. (2002) Cotton Whitefly (Bemisia tabaci) Resistance to Organophosphate and Pyrethroid Insecticides in Pakistan. Pest Management Science, 58, 203-208. http://dx.doi.org/10.1002/ps.440

[14] Nauen, R., Stumpf, N. and Elbert, A. (2002) Toxicological and Mechanistic Studies on Neonicotinoid Cross Resistance in Q-Type Bemisia tabaci (Hemiptera: Aleyrodidae). Pest Management Science, 58, 868-875. http://dx.doi.org/10.1002/ps.557

[15] Roditakis, E., Roditakis, N.E. and Tsagkarakou, A. (2005) Insecticide Resistance in Bemisia tabaci (Homoptera: Aleyrodidae) Populations from Crete. Pest Management Science, 61, 577-582. http://dx.doi.org/10.1002/ps.1029

[16] Erdogan, C., Moores, G.D., Gurkan, M.O., Gorman, K.J. and Denholm, I. (2008) Insecticide Resistance and Biotype Status of Populations of the Tobacco Whitefly Bemisia tabaci (Hemiptera: Aleyrodidae) from Turkey. Crop Protection, 27, 600-605. http://dx.doi.org/10.1016/j.cropro.2007.09.002

[17] Roditakis, E., Grispou, M., Morou, E., Kristoffersen, J.B., Roditakis, N., Nauen, R., Vontas, J. and Tsagkarakou, A. (2009) Current Status of Insecticide Resistance in Q Biotype Bemisia tabaci Populations from Crete. Pest Management Science, 65, 313-322. http://dx.doi.org/10.1002/ps.1690

[18] Luo, C., Jones, C.M., Devine, G., Zhang, F., Denholm, I. and Gorman, K. (2010) Insecticide Resistance in Bemisia tabaci Biotype Q (Hemiptera: Aleyrodidae) from China. Crop Protection, 29, 429-434. 
http://dx.doi.org/10.1016/j.cropro.2009.10.001

[19] Yuan, L., Wang, S., Zhou, J., Du, Y., Zhang, Y. and Wang, J. (2012) Status of Insecticide Resistance and Associated Mutations in Q-Biotype of Whitefly, Bemisia tabaci from Eastern China. Crop Protection, 31, 67-71. http://dx.doi.org/10.1016/i.cropro.2011.09.017

[20] IRAC International Working Group (2014) IRAC MoA Classification Scheme, Version 7.3. http://www.irac-online.org/content/uploads/MoA-classification.pdf

[21] Castle, S., Palumbo, J. and Prabhaker, N. (2009) Newer Insecticides for Plant Virus Disease Management. Virus Research, 141, 131-139. http://dx.doi.org/10.1016/j.virusres.2008.12.006

[22] Stansly, P.A., Kostyk, B. and Riefer, R. (2010) Effect of Rate and Application Method of Cyazypyr (HGW86) on Control of Silverleaf Whitefly and Southern Armyworm in Staked Tomato, 2009. Arthropod Management Tests, 35 , E43.

[23] Jacobson, A.L. and Kennedy, G.G. (2011) The Effect of Three Rates of Cyantraniliprole on the Transmission of Tomato Spotted Wilt Virus by Frankliniella occidentalis and Frankliniella fusca (Thysanoptera: Thripidae) to Capsicum annuum. Crop Protection, 30, 512-515. http://dx.doi.org/10.1016/j.cropro.2010.12.004

[24] Jacobson, A.L. and Kennedy, G.G. (2013) Effect of Cyantraniliprole on Feeding Behavior and Virus Transmission of Frankliniella fusca and Frankliniella occidentalis (Thysanoptera: Thripidae) on Capsicum annuum. Crop Protection, 54, 251-258. http://dx.doi.org/10.1016/j.cropro.2013.08.018

[25] Jacobson, A.L. and Kennedy, G.G. (2014) Electrical Penetration Graph Studies to Investigate the Effects of Cyantraniliprole on Feeding Behavior of Myzus persicae (Hemiptera: Aphididae) on Capsicum annuum. Pest Management Science, 70, 836-840. http://dx.doi.org/10.1002/ps.3626

[26] Govindappa, M.R., Bhemanna, M., Arunkumar, H. and Ghante, V.N. (2013) Bio-Efficacy of Newer Insecticides against Tomato Leaf Curl Virus Disease and Its Vector Whitefly (Bemisia tabaci) in Tomato. International Journal of Applied Biology and Pharmaceutical Technology, 4, 226-231.

[27] Melamed-Madjar, V., Gerson, U. and Tal, S. (1983) A Laboratory Method for Estimating Survival of Tobacco Whitefly Nymphs after Insecticide Treatment, Based on Honeydew Excretion. Phytoparasitica, 11, 25-32. http://dx.doi.org/10.1007/BF02980708

[28] Costa, H.S., Toscano, N.C., Hendrix, D.L. and Henneberry, T.J. (1999) Patterns of Honeydew Droplet Production by Nymphal Stages of Bemisia argentifolii (Homoptera: Aleyrodidae) and Relative Composition of Honeydew Sugars. Journal of Entomological Science, 34, 305-313.

[29] Hendrix, D.L., Wei, Y. and Leggett, J.E. (1992) Homopteran Honeydew Sugar Composition Is Determined by Both Insect and Plant Species. Comparative Biochemistry and Physiology Part B, 101, 23-27.

[30] Llewellyn, M. (1971) The Effects of the Lime Aphid, Eucallipterus tiliae L. (Aphididae) on the Growth of the Lime Tilia $\times$ Vulgaris Hayne. I. Energy Requirements of the Aphid Population. Journal of Applied Ecology, 9, 261-282. http://dx.doi.org/10.2307/2402061

[31] Nauen, R., Koob, B. and Elbert, A. (1998) Antifeedant Effects of Sublethal Dosages of Imidacloprid Bemisia tabaci. Entomologia Experimentalis et Applicata, 88, 287-293. http://dx.doi.org/10.1046/j.1570-7458.1998.00373.x

[32] He, Y., Zhao, J., Wu, D., Wyckhuys, K.A.G. and Wu, K. (2011) Sublethal Effects of Imidacloprid on Bemisia tabaci (Hemiptera: Aleyrodidae) under Laboratory Conditions. Journal of Economic Entomology, 104, 833-838. http://dx.doi.org/10.1603/EC10281

[33] Davidson, E.W., Patron, R.B.R., Lacey, L.A., Frutos, R., Vey, A. and Hendrix, D.L. (1996) Activity of Natural Toxins against the Silverleaf Whitefly, Bemisia argentifolii, Using a Novel Feeding Bioassay System. Entomologia Experimentalis et Applicata, 79, 25-32.

[34] Cameron, R., Lang, E.B., Annan, I.B., Portillo, H.E. and Alvarez, J.M. (2013) Use of Fluorescence, a Novel Technique to Determine Reduction in Bemisia tabaci (Gennadius) (Hemiptera: Aleyrodidae) Nymph Feeding When Exposed to Benevia $^{\mathrm{TM}}$ and Other Insecticides. Journal of Economic Entomology, 106, 597-603. http://dx.doi.org/10.1603/EC12370

[35] Cameron, R., Edward, B. and Alvarez, J.M. (2014) Use of Honeydew Production to Determine Reduction in Feeding by Bemisia tabaci (Hemiptera: Aleyrodidae) Adults When Exposed to Cyantraniliprole and Imidacloprid Treatments. Journal of Economic Entomology, 107, 546-550. http://dx.doi.org/10.1603/EC13369

[36] Liu, T.X. (2004) Toxicity and Efficacy of Spiromesifen, a Tetronic Acid Insecticide, against Sweetpotato Whitefly (Homoptera: Aleyrodidae) on Melons and Collards. Crop Protection, 23, 505-513. http://dx.doi.org/10.1016/j.cropro.2003.10.006

[37] Sethi, A. and Dilawari, V.K. (2008) Spectrum of Insecticide Resistance in Whitefly from Upland Cotton in Indian Subcontinent. Journal of Entomology, 5, 138-147. http://dx.doi.org/10.3923/je.2008.138.147

[38] Shivanna, B.K., Naik, G.B., Nagaraja, R., Basavaraja, M.K., Kalleswara Swamy, C.M. and Karegowda, C. (2011) Bio Efficacy of New Insecticides against Sucking Insect Pests of Transgenic Cotton. International Journal of Science and 
Nature, 2, 79-83.

[39] Horowitz, R., Denholm, I. and Morin, S. (2007) Resistance to Insecticides in the TYLCV Vector, Bemisia tabaci. In: Czosnek, H., Ed., Tomato Yellow Leaf Curl Virus Disease: Management, Molecular Biology, Breeding for Resistance, Springer, Netherlands, 305-325. http://dx.doi.org/10.1007/978-1-4020-4769-5 18

[40] Civolani, S., Cassanelli, S., Chicca, M., Rison, J.L., Bassi, A., Alvarez, J.M., Annan, I.B., Parrella, G., Giorgini, M. and Fano, E.A. (2014) An EPG Study of the Probing Behavior of Adult Bemisia tabaci Biotype Q (Hemiptera: Aleyrodidae) Following Exposure to Cyantraniliprole. Journal of Economic Entomology, 107, 910-919. http://dx.doi.org/10.1603/EC13511

[41] Alvarez, J.M., Portillo, H.E. and Annan, I.B. (2011) The Effect of Cyazypyr ${ }^{\mathrm{TM}}$ in Reducing Hemipteran Pest-Transmitted Diseases in Crop Plants. Proceedings of the Hemipteran-Plant Interactions Symposium, Piracicaba, 76. http://www.infobibos.com/Hemipteran/Proceedings\%20Final.pdf

[42] Alvarez, J.M., Portillo, H.E., Annan, I.B. and Cameron, R.A. (2011) The Role of DuPont Cyazypyr ${ }^{\mathrm{TM}}$ in Reducing InsectTransmitted Plant Diseases. ESA 59th Annual Meeting, Reno. http://esa.confex.com/esa/2011/webprogram/Paper57897.html 